\title{
The New Strategy to The Legitimation of Informal Firms. The Effects of The Signals and Biases on Decisions About Crowdfunding Digital Transformation
}

\author{
Jorge Heredia ${ }^{1}$, Cristian Geldes ${ }^{2 *}$, Alejandro Flores ${ }^{1}$ and Walter Heredia ${ }^{1}$
}

\begin{abstract}
Competition between formal and informal companies has been increasingly studied. However, there is a lack of studies in the collaboration between formal and informal companies generated using crowdfunding platforms. Based on the signaling theory and using the loans from 2019 of the Kiva crowdfunding platform. The drivers and enablers of the collaboration between formally registered firms (partners micro finances) and informal firms (unregistered firms - borrowers) in the context of the crowdfunding digital platform are studied. The results state a negative relationship between the lender's propensity to make loans and the informal firm's percentage borrowed. However, if the borrower receives a trustworthy partner (micro-finance), the borrower's negative impact decreases. Moreover, the lender's propensity to make loans lesser in projects of the tertiary sector. The study contributes to the entrepreneurship theory to understand the mechanism to legitimization the informal firm through collaboration with formal firms in the digital platforms.
\end{abstract}

Keywords Digital transformation, a crowdfunding platform, partner, collaborate, profit, social fi nance, signal, signaling theory, information asymmetry.

Submitted: August $30^{\text {th }}, 2020 /$ Approved: December $15^{\text {th }}, 2020$

\section{Introduction}

The increasing Internet access is transforming the way to do business globally. The incursion of technology-based companies containing digital platforms disrupts the service industries as media, education, finance, and health. This disruption starts with the less sophisticated customer segments and accelerates rapidly toward the more advanced customer segments (Cennamo, 2019). Likewise, new companies applying unique business models based on digital platforms are being created. These technology companies connect suppliers and customers directly at a low cost (including low labor costs) and get a high level of satisfaction for suppliers and customers. Businesses based on technology platforms are overgrowing in emerging economies, especially in Latin America, applying total solutions strategies for customers, incorporating new and valuable complementary services, and developing a sharing economy (Monteiro et al., 2018).

Although business platforms are growing and generating value for users, they are not exempt from criticism as the lack of institutional legitimacy of companies operating on digital platforms, such as the lack of license to offer services, which is why they are qualified unregistered firms. Even so, these companies gain good acceptance by their users. While there are contexts of competition between formal and informal technology-based firms, there are other scenarios where both firms collaborate in the called "inclusive businesses." Formal companies use informal platform companies as part of their production process, generating temporary jobs offered in the so-called gig economy (Duggan et al., 2019). Likewise, informal firms collaborate with legal firms to distribute their products to customers, especially at the pyramid base. These informal platform enterprises use their broad support in social networks, especially at the bottom of the pyramid, to offer various formal enterprises (Tate et al., 2019).
The crowdfunding platforms are not entirely clear within the digital platforms, whether they belong to the formal financial sector or the informal one. These have not been explicitly sanctioned or considered illegal but are preferably supported especially by the Chinese authorities as an alternative way to informal financing that can lead to financial instability in the system, a sample of which is the approval in late 2014 of a regulation based on in shares (Funk, 2019). Moreover, the crowdfunding platforms allow collaboration between formal and informal firms to develop new businesses (Schwittay, 2019).

Although the strategic competition between formal and informal enterprises has been a topic in several studies, finding positive and negative relationships (Heredia et al., 2019). However, there is a gap in the management literature related to understanding the cooperation relationship between formal and informal enterprises and how it affects funding success. The phenomenon has been accelerated using digital platforms resulting from the COVID 19 pandemic. Indeed, most formal companies are increasing digital platforms' use to provide a better service experience to their customers, seek new strategic partners and improve their performance in this digital environment (Heredia et al., 2020). This phenomenon occurs in the Kiva crowdfunding platform, which collaborates between formal and informal companies. Thus, the study aims to analyze the success factor in financing projects using the signaling theory. It allows hypothesizing that the interaction between formal and informal firms can generate collaboration instead of competition and thus mutually benefit. It is observed by reducing the negative impact of the low perceived need and low trust of the lender on the percentage that the loan managed to be financed by the informal firm.

\footnotetext{
1) Management at School of Business, Universidad del Pacífico, Lima, Perú

2) Faculty of Economics and Business, Universidad Alberto Hurtado, Santiago, Chile

*Corresponding author: cgeldes@uahurtado.cl
} 
Kiva, a popular crowdfunding platform, connects people who need funding for their project, whether social, humanitarian or entrepreneurship, profit, with people who want to allow borrowers around the world. Kiva is a platform that permits that entrepreneurs and others in financial need can gain access to funding through relatively small contributions from a relatively large number of individuals and circumventing standard financial intermediaries (Schwienbacher \& Larralde, 2012).

The study data are collected by the webpage Kiva Tools, which contains files with information about the credits, characteristics of the partners, and borrowers currently on the Kiva website. Additionally, it is included the logarithm of popularity as a proxy variable for the lenders' characteristics to have the interaction of all the actors: lenders, borrowers (informal firms), and partners (formal microfinance firms). A multivariate analysis using the ordinary least squares (OLS) technique is built, and it includes variables based on the published works related to the determinants of funding success across all platform types (e.g., Moleskis et al., 2018). Some of these variables are the characteristics of the loan like rating risk, economic and social value, the number of borrowers and competition among projects, type of project: entrepreneurial or social project, as well as the characteristics of the borrower, such as gender, geography, network, and social capital (e.g., Shier \& Handy).

In sum, this study analyzes the collaboration between formal (partners microfinance) and informal companies (borrowers) and its effects on the relation of lenders and borrowers (informal firms), using the case of the Kiva crowdfunding platform. Including the loan analyses (if it belongs to the tertiary sector or not) on this collaboration. To respond to the research question: What conditions propend collaboration between formal and informal firms in industries with disruption in digital transformation as the crowdfunding platforms? The next sections include the theoretical framework and hypothesis, methodology and data, results, conclusions, and implications.

\section{Theoretical framework and hypothesis}

The lenders lend without receiving any interest in the risk of losing their money, so they donate the opportunity cost of the interest. They donate because the economic capacity and inclination to give are enough (Schlegelmilch et al., 1997). This behavior is also affected by demographic factors such as age, religious beliefs, gender, and ethnicity (e.g., Shier \& Handy, 2012). Another perspective explains that the people donate because they expect to receive material or immaterial benefits in return for their donations, including the effect of a warm glow, feelings of higher self-esteem, public recognition, or relief from guilt (Diamond \& Kashyap, 1997). Many studies about charity acknowledge that the internet is a powerful way to sensitize people to help those in need and solicit help. Kiva is a platform that allows the encounter between people who need support and opportunity and others who can support them worldwide.

Moreover, Kiva is an easy way for all participating agents to win. The underprivileged borrowers get the necessary funds to start their projects, whether profit or not. The lenders can help without thinking about the transaction costs because Kiva eliminates them by not charging fees and maintains an easy process for (re) investing that creates efficiency. Like microfinance institutions (MFIs), some partners benefit from having more clients because they have more loans in their portfolios and perceive social responsibility benefits. Finally, both lenders and partners benefit from the social reputation that can enjoy by the publicity and social networks.

This study proposes that in Kiva, when an informal company (borrower) is found with a formal company (partner), unlike if it finds with another informal one (characteristic of the loan), a type of collaboration between them is generated, thus obtaining a mutual benefit because the lenders of Kiva have both prosocial and economics motivations. The lenders act for their desire to help other people, but they care about the loan's repayment and its efficient use. In this way, they also ensure that more people can get the same opportunity to obtain financing to start their projects.

\subsection{Information asymmetry and signaling}

In crowdfunding, information asymmetry is presented because the lenders do not have the same information as borrowers if they think or pay their requests. Furthermore, two broad types of information asymmetry can be present in crowdfunding as information about quality and intent. The intention is critical because it shows the agent's behavior, and intentions examine the use of incentives as mechanisms for reducing potential moral hazards that result from an individual's behavior (Jensen \& Meckling, 1976). Otherwise, another way to deal with information asymmetry is through signals. Individuals use signals to resolve information asymmetries about latent and unobservable quality.

According to signaling theory, the lenders and borrowers have access to different information because while it is right lenders do not receive any interest in lending their money, they can lose their money if the borrowers do not return what they lent even when the repayment rate is high ( $96.7 \%$ according to Kiva). The use of signals is an excellent way to amend this asymmetry. In this sense, the lenders have to look for signs to make sure they do not lose their money since losing their money takes away the possibility that another or others can also be financed later and might lose an opportunity to improve their lives. Thus, the partner shows a good or reliable characteristic is taken as a good signal for the lenders and thus generates a positive way to impact the loans' funding process. The signaling theory in the studies about crowdfunding is essential; this theory has been fundamental in combatting information asymmetry in investment decisions (e.g., Ahlers et al., 2015).

Moleskis et al. (2018) studied how the factors influencing the likelihood of funding success vary for projects (humanitarian or entrepreneurial projects). Also, there are studies of this theme, specifically about Kiva. Vismara (2018) proposed a taxonomy of signals that matches the senders-namely, such organizations as firms and nongovernmental organizations and individuals, including both proponents and fellow crowd-funders-and receivers, like backers, lenders, and investors to overcome inefficiencies in Crowdfunding Markets. 


\subsection{Crowdfunding}

Crowdfunding is a type of crowdsourcing where customers play as investors (Zheng et al., 2014). Crowdfunding is an effective funding channel to get small to medium-size investments from the crowd (Ordanini, 2009). Schwienbacher and Larralde (2012) identify three crowdfunding business models: donation, passive investment, and active investment. The first crowdfunding business model is that the donation model is more popular and implemented by non-governmental organizations. The second crowdfunding business model is a passive investment. The crowdfunding sponsors have limited interaction and communications with entrepreneurs but still aim to get rewards, tailored products, honorary recognitions, or other revenue sharing forms from the crowdfunding projects. Finally, the active investment provides crowdfunding sponsors the opportunities to invest money and continually interact with entrepreneurs, such as helping entrepreneurs with new features, testing products, and providing directions and feedback (Schwienbacher and Larralde, 2012). According to this concept, Kiva belongs at the first crowdfunding model: donations because the lenders or investors do not receive financial rewards and the partners, which can be microfinance institutions (MFIs), social enterprises, and nonprofits organizations, only have limited interaction and communication with the borrower or borrowers that request the credit, they administer the loan, they post the loans on Kiva platform and make the risk rating of the loan. In the case of Kickstarter, it belongs to the second crowdfunding model: passive investment because the investors receive some form of rewards; these rewards can take different forms; however, they do not receive the control of the project, or they are not being used as active consumers. The kind of crowdfunding platforms that receive some form of reward let us call them "profit."

In the studies about crowdfunding platforms, an important conclusion is that a project's popularity positively affects its financing since it is a "rational" decision of the backers to support such projects to reduce their own risk (Zhang and Liu, 2012). However, these studies have been carried out using profit platforms such as Kickstarter, Indiegogo, and Gofundme, but its objective and dynamic are different in Kiva's case. In line with the concepts presented before, this study proposes the first hypothesis that in the kiva crowdfunding platform, unlike other crowdfunding platforms that are profit, lenders take variable popularity as a sign that there is no need urgently to be financed. Kickstarter states that "longer durations incite less urgency, encourage procrastination, and tend to fizzle out" (Harrison, 2017). Since they perceive that they have just been published on the platform and, therefore, still have time to raise funds, unlike those already going to expire.

H1: "The logarithm of popularity, as the signaling of the urgent need perceived by the lender, has a negative relationship with the percentage of loans borrowed by informal firms."

\subsection{Digital transformation and cooperation between informal and formal firms}

In the digital transformation context, established companies react to maintain their competitive advantage in digital disruption environments (Weill \& Woerner, 2018). Digital platforms are not alien to this process because they need to develop strategic dimensions as the network effect and platform identity (Cennamo, 2019). Moreover, in the digital platforms as Kiva and Go-Jek multi-service platform gives access to small informal entrepreneurs sell their products through this mobile APP, allowing small entrepreneurs to increase the possibility of access to more customers. It generates a relationship of cooperation between informal and formal firms.

Studies about the cooperation between informal and formal firms are less common than investigations of the competition between informal and formal firms. In the specific case of innovation, Bönte \& Keilbach (2005) found weak empirical evidence for incoming knowledge spillovers' relevance for formal and informal cooperation. However, the firm's ability to protect its proprietary innovations has a positive effect on a firm's propensity to engage in formal and informal cooperation at the same time. Other research proposes that the high complexity of knowledge-intensive work, such as software development, makes it beneficial to have formal and informal articulation work (Boden et al., 2014). Other studies have shown that formal firms use informal platform companies as part of their production process, generating temporary jobs offered in the so-called gig economy (Duggan et al., 2019).

The level of cooperation between formal and informal firms can increase the legitimate to the informal firm activity. The informal firm can then access more formal financial activities (Frydrych et al., 2014); due to the information's asymmetry, the lenders must see signals to invest. A way to get signals is seeing a good signal from the partner, and that is where collaboration is generated; the partners lend their good signal to benefit the borrowers to get more funds. Since they have more loans, the parties benefit more from getting more clients. Even if it is of lower profitability than their standard portfolio but has benefits for having more loans placed instead of idle money, they have a better reputation and benefit from social responsibility and popularity. However, it runs the risk that the lenders do not receive all the necessary funds and have already deposited the borrower, and that the borrower does not pay him. However, that risk is low (3.2\%, according to Kiva). In Kiva, we can see the same phenomenon. Thus, we hypothesize as follows:

H2: "A good characteristic of the partner expressed by a good portfolio yield (formal firm) reduces the negative relation between Logarithm of popularity, as the signaling the level of an urgent need perceived by the lender, on percentage funded of the informal firm."

\subsection{Tertiary sector}

In Kiva's case, the loans destined for the tertiary sector are used to finance entrepreneurial projects that are not of the humanitarian type. Therefore, if the lenders do not see a signal from the partner and see that the credit is more for business services or businesses, they do not see any sign that the probability of losing money decreases, and that goes for a project that can be said not very social. Besides, the service sector offers a not differentiated product with a low technology level and is more prone to get more informal firms (Heredia et al., 2019). It increases the risk of financing this type of entrepreneurship as a restaurant service and reduces the lenders' propensity to invest. That is why we propose the following hypothesis: 
H3: "The characteristic of the loan the project as the tertiary sector, strengthens the negative relation between Logarithm of popularity, as the signaling the level of an urgent need perceived by the lender, and the percentage funded of the informal firm."

Figure 1: Proposed model.

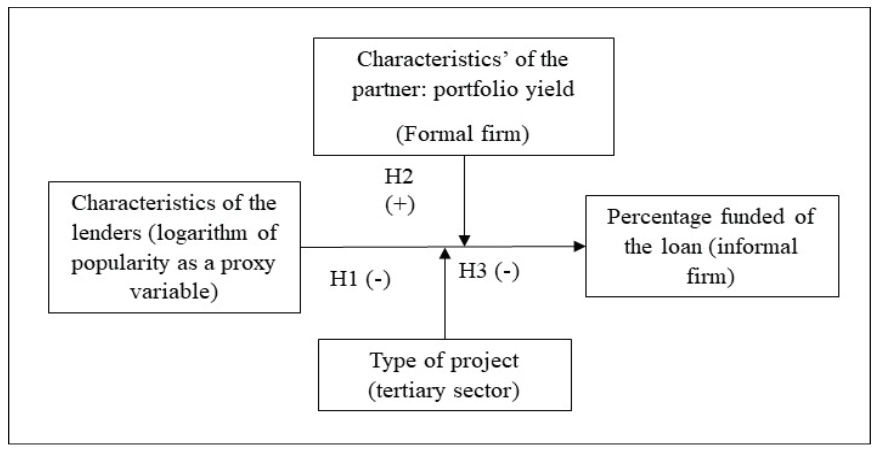

\section{Methodology and data}

A multivariate analysis using the ordinary least squares (OLS) technique is designed to test the proposed model's hypothesis. It includes three models considering the model fit requirements (Heredia et al.,2019). The dependent variable is the "percentage financed of loans," and the independent variables are obtained from related literature. Table 1 shows a description, explanations, and literature source of each variable included in the models. Model 1 includes de Logarithm of popularity and the independent variables as control variables. Model 2, in addition to Model 1, adds the "partner portfolio yield" and its moderation effect: "Logarithm popularity x partner portfolio yield." Model 3 analyzes the effect of moderation of "tertiary," including "Logarithm popularity x tertiary."

Table 1: Variable definitions

\begin{tabular}{|c|c|c|c|c|c|c|}
\hline Variables & Expected sign $\beta$ & Obs. & Mean & S.D. & Min & $\operatorname{Max}$ \\
\hline Percent funded of loans (1) & & 2079 & 16.09 & 20.53 & 0 & 97.42 \\
\hline The Logarithm of popularity (2) & $(-)$ & 2079 & 7.19 & 1.05 & 0.69 & 8.25 \\
\hline Partner portfolio yield (3) & $(+)$ & 2003 & 3.57 & 0.35 & 1.91 & 4.12 \\
\hline Tertiary (4) & $(+)$ & 2079 & 0.34 & 0.47 & 0 & 1 \\
\hline The number of loans posted currently by the partner (5) & $(-)$ & 2070 & 156.7 & 129.7 & 0 & 385 \\
\hline Average loan size percent per capita income of the partner (6) & $(-)$ & 2070 & 53.52 & 57.95 & 0 & 211.2 \\
\hline Repayment term (7) & $(-)$ & 2027 & 16.94 & 6.71 & 6 & 62 \\
\hline Asia (8) & $(-) /(+)$ & 2079 & 0.29 & 0.45 & 0 & 1 \\
\hline Lars Ratio (9) & $(-)$ & 2079 & 4.91 & 40.15 & 0.03 & 1474 \\
\hline Time left (days) (10) & $(-)$ & 2079 & 2.51 & 7.77 & 0.04 & 29.98 \\
\hline Fundraising rate per hour (11) & $(+)$ & 2079 & 1.51 & 4.81 & 0 & 86.71 \\
\hline Partner default rate (12) & $(-)$ & 2079 & 1.02 & 1.66 & 0 & 8.62 \\
\hline Logarithm partner amount raised (13) & $(+)$ & 2070 & 16.00 & 1.03 & 11.70 & 18.06 \\
\hline The Logarithm of the amount posted (14) & $(-)$ & 2070 & 16.00 & 1.03 & 11.70 & 18.06 \\
\hline Central America (15) & $(-) /(+)$ & 2079 & 0.11 & 0.31 & 0 & 1 \\
\hline Female (16) & $(+)$ & 2079 & 0.59 & 0.49 & 0 & 1 \\
\hline The profitability of the partner (17) & $(+)$ & 2070 & 2.01 & 4.78 & -26.4 & 65.82 \\
\hline Repayment monthly (18) & $(-)$ & 2027 & 0.86 & 0.33 & 0 & 1 \\
\hline South America (19) & $(-) /(+)$ & 2079 & 0.06 & 0.24 & 0 & 1 \\
\hline
\end{tabular}

(1) The percentage that the loan managed to be financed (Frydrych et al., 2014).

(2) Natural Logarithm of the number of visits that the loan profile has on the Kiva platform (Kuppuswamy \& Bayus, 2013).

(3) Performance of the partner's portfolio (Moleskis et al., 2018).

(4) Dummy variable: (1) if the purpose of the loan is to produce services, (0) the purpose of the loan is not for services (Moleskis et al., 2018).

(5) The number of current credits the partner supported on Kiva (Frydrych et al., 2014).

(6) This ratio is useful to measure the partner's performance (Frydrych et al., 2014).

(7) It is the number of loan repayment periods (Ly \& Mason, 2012).

(8) Dummy variable: (1) if the person requesting the loan belongs to a country in the Asian continent; (0) if otherwise (Ly \& Mason, 2012).

(9) It is the average hourly financing needed for a fully funded loan (Moleskis et al., 2018).

(10) It is the number of days left before it leaves the platform (Ly \& Mason, 2012).

(11) The amount of money the loan gets per hour (Frydrych et al., 2014).

(12) Default rate = amount of ended loans defaulted / amount of ended loans (Frydrych et al., 2014),

(13) It is the Natural Logarithm of the amount of money that the partner has managed to invest until that moment (Moleskis et al., 2018).

(14) The natural logarithm of the amount of money that the partner is currently supporting on the platform (Moleskis et al., 2018).

(15) Dummy variable: (1) if the person requesting the loan belongs to a country of Central America; (0) if otherwise (Ly \& Mason, 2012).

(16) Dummy variable: (1) the request of loan is female; (0), if otherwise (Ly \& Mason, 2012).

(17) It is the partners' current profitability that they obtain for supporting loans (Ly \& Mason, 2012).

(18) Dummy variable: (1) if the loan has as repayment schedule months; (0), if otherwise (Ly \& Mason, 2012).

(19) Dummy variable: (1) if the person requesting the loan belongs to a country of South America; (0), if otherwise (Ly \& Mason, 2012). 


\subsection{Data}

The data were obtained from the Kiva crowdfunding platform on November 6, 2019. It corresponds to 2,080 observations with information on the loans, borrowers' characteristics, and partners. Formal businesses are mostly partnering like microfinance services. Also, there are schools and social organizations. All these organizations share the desire to improve people's lives through safe, fair access to credit. The informal firms are the borrowers that, in general, cannot access the financial system, or it is costly for them.

\section{Results and discussion}

The study is focused on analyzing the effects of the collaboration between informal and formal firms on the percentage that Kiva's loans are funded. In this line, the first result indicates that the "Logarithm of popularity" is significantly correlated negatively with the "percent funded of loans." Also, there are significant correlations between "percent funded" and other control variables the "number of loans posted currently by the partner," "average loan size percent," "per capita income of the partner," "repayment term," "Asia," "partner delinquency rate," "Lars ratio," "the number of days left until expiration," "fundraising rate per hour," "partner default rate," "Logarithm of the amount posted," "Central America," "female," "the profitability of the partner," "repayment monthly," and "South America country."

The Logarithm of popularity is considered a proxy variable of the number of lenders due to limited available data. Figure 2 shows the direct relationship between the time left for the credit profile to leave the Kiva platform and popularity. It shows that with more time left in Kiva, the organization will get less financing percentage of its credit since the lenders do not see it as urgent to finance the loans that just or have little time on the platform.

Figure 2: Graphic analysis of popularity and time in Kiva.

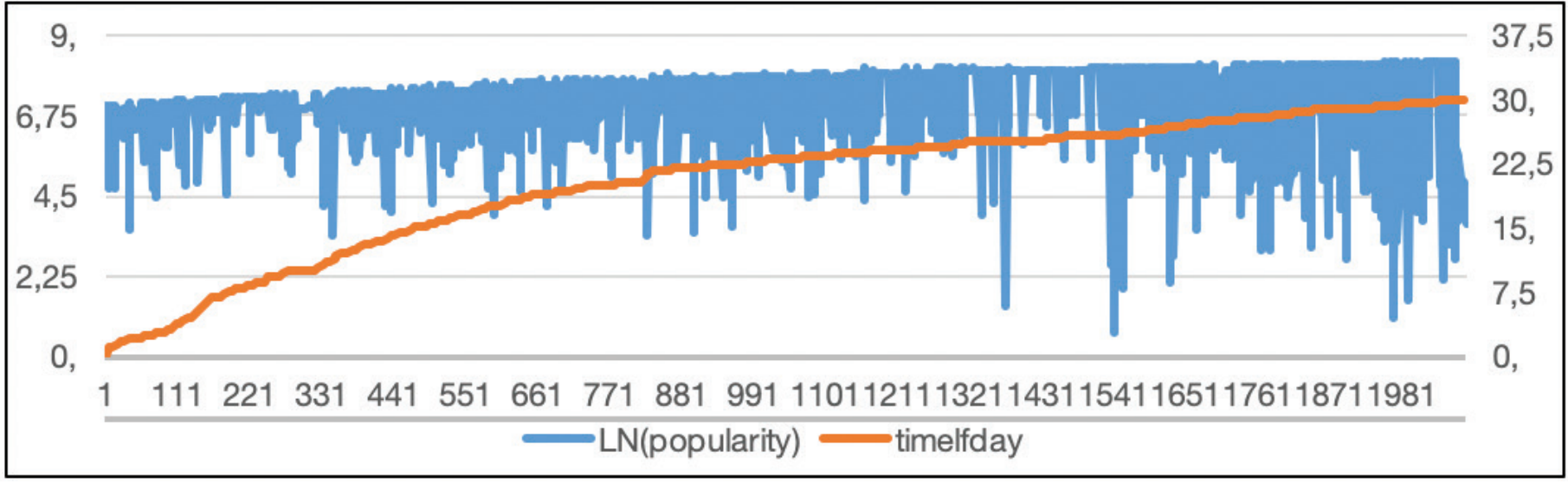

The results of the ordinary least squares (OLS) are shown in Table 2. Model 1 states that the independent variable Logarithm of popularity has a significant effect on percent funded of loans, providing support for H1. This finding indicates that the percent funded can be higher by having less popularity from the lenders. It can be explained because the lenders can see that a loan profile is prevalent or has many visits; they will see it as a sign of no need for urgency to choose another. Model 2 and Model 3 confirm this result.
The results of Model 2 indicate that the partner's excellent characteristic expressed by a good portfolio yield moderates the relationship between the Logarithm of popularity and percent funded, providing support for H2. This finding shows that good portfolio yield significantly affects the role of the Logarithm of popularity as a good signal perceived by lenders to finance loans. When the partner has a good portfolio yield, the negative relationship between the Logarithm of popularity and percent funded is weakened. Similarly, it is founded that the negative relationship between the Logarithm of popularity and percent financed is strengthened when the loan belongs to the tertiary or service sectors. This result supports the H3. 
Table 2: Regression results

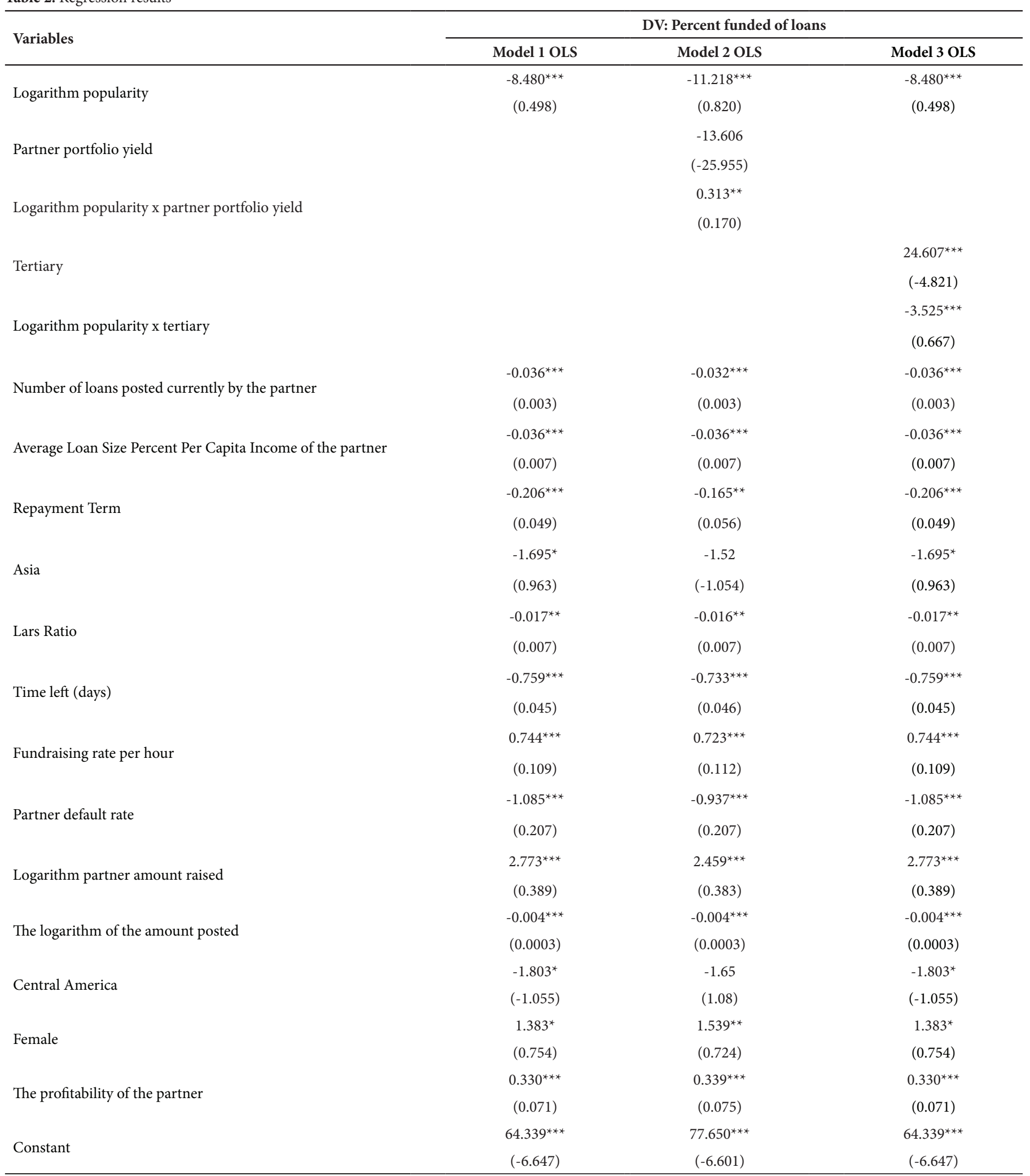

Significant at $10 \%^{*}$, Significant at $5 \%^{* *}$, Significant at $1 \%^{* * *}$ 
The results show that when the partner gives a good signal, the negative relationship between the Logarithm of popularity and the percentage of loan financing in Kiva is weaker - generating collaboration between the formal and informal. It means a moderating role of partner portfolio yield (Figure 3).

Figure 3: Moderating role of partner portfolio yield

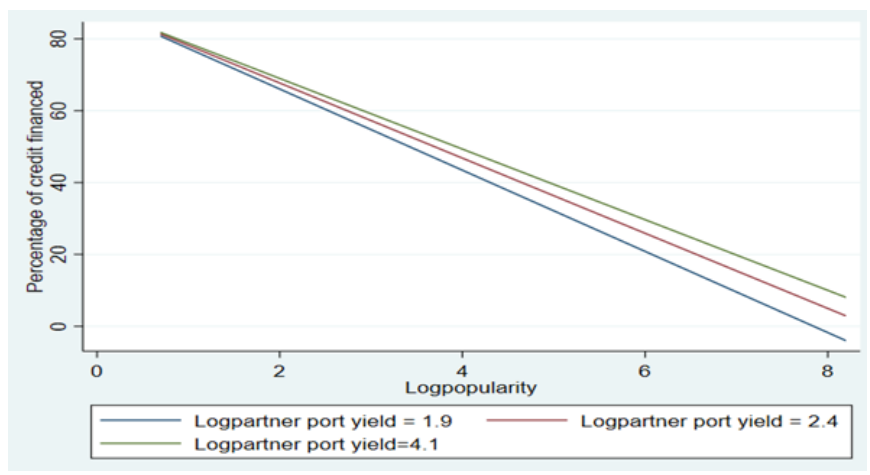

In contrast, there is a moderating role of tertiary (if the organization belongs to the tertiary sector). Figure 4 shows that if the loan is aimed at the tertiary or services sector, it will strengthen the relationship's negative effect.

Figure 4: Moderating role of tertiary.

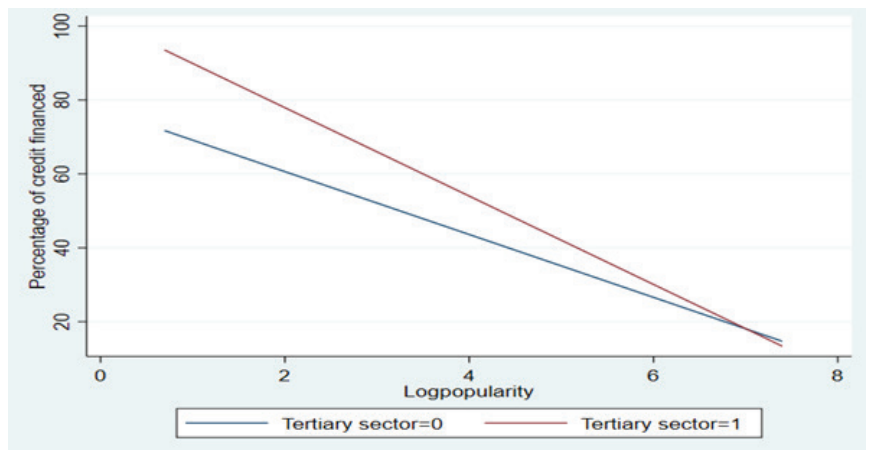

\section{Conclusion and implications}

The analysis and results allow us to conclude that the hypothesis of the proposed model is confirmed. This means that the logarithm of popularity, as the signaling of the lender's urgent need, negatively relates to the percentage of loans borrowed by informal firms. The logarithm of popularity must be understood as a proxy variable of the characteristics of the lenders.

Additionally, a good characteristic of the partner expressed by a good portfolio yield (formal firm) reduces the negative relation (moderate) between Logarithm of popularity, as the signaling the level of the urgent need perceived by the lender, on percentage funded of the informal firm (H2), and the characteristic of the loan the project as the tertiary sector, strengthens the negative relation (moderate) between Logarithm of popularity, as the signaling the level the urgent need perceived by the lender, and the percentage funded of the informal firm (H3).
The study's findings provide new insights into understanding how the conclusions of many studies on crowdfunding obtained so far may change depending on what type of crowdfunding is analyzed. The results are different from Kickstarter, Indiegogo, and other profit platforms, which conclude that more popularity of a project translates into a greater financing probability because the sponsors reduce their financing risk (Zhang and Liu, 2012).

The collaboration between informal and formal firms can be generated on a digital platform and how this benefits the percentage of loan financing in Kiva. The study will extend these previous theories of the study of the interaction between formal and informal enterprises to the context of emerging economies to develop more insight, which allows us to understand these companies' behavior (formal and informal) in industries that suffer or have high potential disruption. Recent studies on the interaction of formal and informal firms in emerging economies (Heredia et al., 2018; Heredia et al., 2019).

The main limitation of the study is access to the data. It analyzed only a sample of loans from the Kiva.org microcredit platform. Another limitation is that the research was conducted only on this platform. Although the number of loans taken as the sample was comparatively large, there can be some bias due to the Kiva platform's unique features (Kiva Teams and Field Partners). It would be interesting to analyze the effects of a time horizon. Additionally, future research may perform the analysis by sector, industry, considering the lender's information.

\section{References}

Ahlers, G. K., Cumming, D., Günther, C., \& Schweizer, D. (2015). Signaling in equity crowdfunding. Entrepreneurship theory and practice, 39(4), 955-980. https://doi.org/10.1111/etap.12157

Boden, A., Rosswog, F., Stevens, G., \& Wulf, V. (2014). Articulation spaces: bridging the gap between formal and informal coordination. Proceedings of the 17th ACM Conference on Computer Supported Cooperative Work \& Social Computing. https:// doi:10.1145/2531602.2531621

Bönte, W., \& Keilbach, M. (2004). Concubinage or Marriage? Informal and Formal Cooperations for Innovation. SSRN Electronic Journal. https://doi:10.2139/ssrn.546102

Cennamo, C. (2019). Competing in Digital Markets: A PlatformBased Perspective. Academy of Management Perspectives. https:// doi:10.5465/amp.2016.0048

Connelly, B. L., Certo, S. T., Ireland, R. D., \& Reutzel, C. R. (2011). Signaling theory: A review and assessment. Journal of Management, 37(1), 39-67. https://doi.org/10.1177/0149206310388419

Diamond, W. D., \& Kashyap, R. K. (1997). Extending Models of Prosocial Behavior to Explain University Alumni Contributions 1. Journal of Applied Social Psychology, 27(10), 915-928. https:// doi:10.1111/j.1559-1816.1997.tb00278.x 
Duggan, J., Sherman, U., Carbery, R., \& McDonnell, A. (2019). AppWork, Algorithmic Management \& HRM in the Emerging Gig Economy: A Research Agenda. Academy of Management Proceedings, 2019(1), 15773. https://doi:10.5465/ambpp.2019.15773abstract

Frydrych, D., Bock, A. J., Kinder, T., \& Koeck, B. (2014). Exploring Entrepreneurial Legitimacy in Reward-Based Crowdfunding. Venture Capital, 16(3), 247-269. https://doi:10.1080/13691066.2014.916512

Funk, A. S. (2019). Crowdfunding in China. Crowdfunding in China, 149-198. https://doi:10.1007/978-3-319-97253-4_5

Harrison, R. T. (2017). Crowdfunding and Entrepreneurial Finance. Routledge https://doi:10.4324/9781315682440

Heredia Pérez, J. A., Kunc, M. H., Durst, S., Flores, A., \& Geldes, C. (2018). Impact of Competition from Unregistered Firms On R\&D Investment by Industrial Sectors in Emerging Economies. Technological Forecasting and Social Change, 133, 179-189. https://doi:10.1016/j. techfore.2018.03.028

Heredia Pérez, J. A. H., Yang, X., Bai, O., Flores, A., \& Heredia, W. H. (2019). How Does Competition by Informal Firms affect the Innovation in Formal Firms? International Studies of Management \& Organization, 49(2), 173-190. https://doi:10.1080/00208825.2019.1608402

Heredia, J., Heredia, W., \& Flores, A. (2020). The Role of Information Technology to Build Capabilities in Inclusive Businesses: A Case Study in China and Peru's Cosmetic Industry. Academy of Management Global Proceedings (2020), 200.

Jensen, M. C., \& Meckling, W. H. (1976). Theory of the firm: Managerial behavior, agency costs and ownership structure. Journal of Financial Economics, 3(4), 305-360. https://doi:10.1016/0304$405 x(76) 90026-x$

Kuppuswamy, V., \& Bayus, B. L. (2013). Crowdfunding Creative Ideas: The Dynamics of Project Backers in Kickstarter. SSRN Electronic Journal. https://doi:10.2139/ssrn.2234765

Ly, P., \& Mason, G. (2012). Individual preferences over development projects: Evidence from microlending on Kiva. Voluntas: International Journal of Voluntary and Nonprofit Organizations, 23(4), 10361055. http://dx.doi.org/10.1007/s11266-011-9255-8

Moleskis, M., Alegre, I., \& Canela, M. A. (2018). Crowdfunding Entrepreneurial or Humanitarian Needs? The Influence of Signals and Biases on Decisions. Nonprofit and Voluntary Sector Quarterly, 48(3), 552-571. https://doi:10.1177/0899764018802367
Monteiro F. L., Rozman G., Carrick A. M. (2018). Digital Transformation in Latin America: A Leapfrogging Opportunity? Harvard Business Publishing Education, 1-56.

Ordanini, A. (2009). Crowdfunding: customers as investors. The Wall Street Journal, 23(3), 5-7.

Schlegelmilch, B. B., Love, A., \& Diamantopoulos, A. (1997). Responses to different charity appeals: the impact of donor characteristics on the amount of donations. European Journal of Marketing, 31(8), 548-560. https://doi:10.1108/03090569710176574

Schwienbacher, A., \& Larralde, B. (2012). Alternative types of entrepreneurial finance. In The Oxford Handbook of Entrepreneurial Finance. http://doi:10.1093/oxfordhb/9780195391244.013.0013

Schwittay, A. (2019). Digital Mediations of Everyday Humanitarianism: The Case of Kiva.Org. Third World Quarterly, 40(10), 1921-1938. https://doi:10.1080/01436597.2019.1625267

Shier, M. L., \& Handy, F. (2012). Understanding online donor behavior: the role of donor characteristics, perceptions of the internet, website and program, and influence from social networks. International Journal of Nonprofit and Voluntary Sector Marketing, 17(3), 219-230. https://doi:10.1002/nvsm.1425

Tate, W. L., Bals, L., \& Marshall, D. (2019). Supply Chain Management at The Base of the Pyramid. International Journal of Physical Distribution \& Logistics Management, 49(5), 438-450. https://doi:10.1108/ ijpdlm-06-2019-390

Vismara, S. (2018). Signaling to Overcome Inefficiencies in Crowdfunding Markets. The Economics of Crowdfunding, 29-56. https:// doi:10.1007/978-3-319-66119-3_3

Vismara, S. (2018). Information cascades among investors in equity crowdfunding. Entrepreneurship Theory and Practice, 42(3), 467-497. https://doi.org/10.1111/etap.12261

Weill, P., \& Woerner, S. L. (2018). Is your company ready for a digital future? MIT Sloan Management Review, 59(2), 21-25.

Zhang, J. J., and Liu, P. (2012). Rational Herding in Microloan Markets. Management Science, 58(5), 892-912. https://doi.org/10.1287/ Mnsc.1110.1459

Zheng, H., Li, D., Wu, J., \& Xu, Y. (2014). The role of multidimensional social capital in crowdfunding: A comparative study in China and US. Information \& Management, 51(4), 488-496. https:// doi:10.1016/j.im.2014.03.003 
J. Technol. Manag. Innov. 2020. Volume 15, Issue 4 